\title{
THE RENAL EXCRETION OF INOSITOL BY NORMAL AND DIABETIC RATS ${ }^{1}$
}

\author{
By WILLIAM H. DAUGHADAY AND J. LARNER ${ }^{2}$ WITH THE TECHNICAL ASSISTANCE OF \\ ELLABETH HOUGHTON
}

\author{
(From the Departments of Medicine and Biological Chemistry, Washington University School \\ of Medicine, St. Louis, Mo.)
}

(Submitted for publication January 22, 1954 ; accepted April 8, 1954)

Inositol is excreted in the urine of patients with diabetes mellitus in greatly increased amounts. Although this fact has been known since 1859, the cumbersome analytic procedures for inositol have prevented a thorough study of the mechanism of this abnormality (1). In an earlier publication from this laboratory a microbiologic assay was employed in clinical studies of the urinary excretion by normal and diabetic human beings (2). The increased amounts of inositol found in the urine of diabetic patients was related to glycosuria rather than to polyuria. The renal clearance of inositol was found to be much higher in diabetic than in non-diabetic patients and the administration of large amounts of glucose intravenously to nondiabetic patients raised the renal clearance of inositol to levels found in uncontrolled diabetic patients.

A comparable increase in the excretion of inositol in the urine of diabetic rats has been found. This report presents evidence that the inositol appearing in the urine of diabetic rats is largely of dietary origin. The mechanism of inositol excretion has been studied in the rat and observations are described which demonstrate that a mechanism exists for the tubular reabsorption of inositol which is inhibited by glucose and phlorizin but not by a saline diuresis. It is proposed that the renal tubular systems for the transport of glucose and inositol may be closely related.

\section{METHODS}

Adult male rats of the University of Illinois stock colony were subjected to subtotal pancreatectomy and

1 This work was supported by a grant-in-aid from the Nutrition Research Foundation.

2 This work was begun while holding a Postdoctorate Fellowship of the National Institutes of Health, and continued while a Fellow of the Life Insurance Medical Research Foundation. Present address: Division of Biochemistry, Noyes Chemical Laboratory, University of Illinois, Urbana. were utilized in the experiments summarized in Table I. In all other experiments adult male Sprague-Dawley rats were used. Diabetes was induced by the intravenous administration of 45 to $60 \mathrm{mg}$. per $\mathrm{Kg}$. of alloxan (Eastman). A period of one to three weeks was allowed for the recovery from the renal damage resulting from alloxan. The presence of diabetes was confirmed by measuring the level of glucose in the blood and urine.

The excretion of inositol by partially depancreatized and normal rats on low, medium, and high intakes of inositol has been measured (Table $\mathrm{I} A$ ). Diet $\mathrm{A}$ was a purified diet ${ }^{3}$ low in inositol (0.08 mg. per Gm.). Diet $B$ was Purina Fox Chow which on analysis was found to contain $2.7 \mathrm{mg}$. of inositol per $\mathrm{Gm}$. High inositol intake (Diet C) was obtained by feeding Fox Chow and adding inositol to the drinkng water. Because of the difference in fluid intake, $70 \mathrm{mg}$. of inositol per $\mathrm{ml}$. of water was added for normal rats and $7 \mathrm{mg}$. of inositol per $\mathrm{ml}$. for the partially depancreatized rats. After the animals had been eating the diet for six days the inositol excreted in the urine was measured. During the period of study rats were housed in metabolism cages and urine was collected under toluene, free of feces.

In the observations on alloxan diabetic rats (Table I $B$ ) the low inositol diet was fed for three days. Inositol was then added to the drinking water (100 mg. per $\mathrm{ml}$. for normal rats and $50 \mathrm{mg}$. per $\mathrm{ml}$. for diabetic rats).

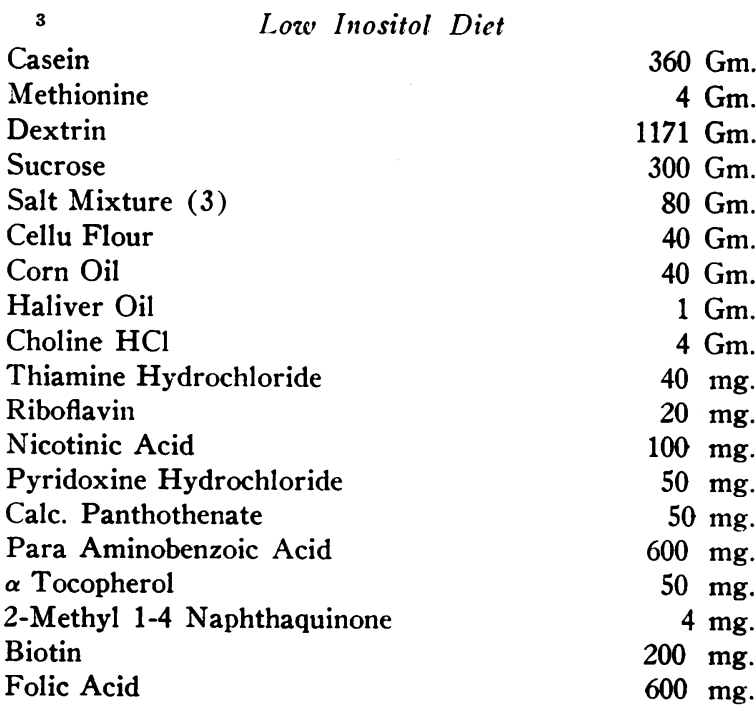


TABLE I

Mean excretion of inositol by normal and partially depancreatized and alloxan diabetic rats

\begin{tabular}{|c|c|c|c|c|c|c|}
\hline & Diet & $\begin{array}{l}\text { Number } \\
\text { of rats }\end{array}$ & $\begin{array}{l}\text { Urine } \\
\text { vol: } \\
m l:\end{array}$ & $\begin{array}{c}\text { Urine } \\
\text { sugar } \\
G m . / 24 h r s .\end{array}$ & $\begin{array}{c}\text { Inositol } \\
\text { intake } \\
m g . / 24 \text { hrs. }\end{array}$ & $\begin{array}{c}\text { Urine } \\
\text { inositol } \\
m g . / 24 \text { hrs. }\end{array}$ \\
\hline \multicolumn{7}{|c|}{$A$} \\
\hline Normal rats & $\begin{array}{l}\text { A } \\
\text { B } \\
\text { C }\end{array}$ & $\begin{array}{l}2 \\
2 \\
4\end{array}$ & $\begin{array}{r}10 \\
8 \\
6\end{array}$ & E & $\begin{array}{r}1.4 \\
41.0 \\
1,623.0\end{array}$ & $\begin{array}{l}0.2 \\
0.5 \\
0.7\end{array}$ \\
\hline Depancreatized rats & $\begin{array}{l}\mathrm{A} \\
\mathrm{B} \\
\mathrm{C}\end{array}$ & $\begin{array}{l}4 \\
4 \\
6\end{array}$ & $\begin{array}{l}231 \\
153 \\
169\end{array}$ & $\begin{array}{l}19.1 \\
11.0 \\
15.6\end{array}$ & $\begin{array}{r}3.3 \\
114.0 \\
1,426.0\end{array}$ & $\begin{array}{r}2.5 \\
20.0 \\
400.0\end{array}$ \\
\hline $\begin{array}{l}\text { Depancreatized rats after } \\
\text { insulin treatment }\end{array}$ & $\begin{array}{l}\mathrm{A} \\
\mathrm{B} \\
\mathrm{C}\end{array}$ & $\begin{array}{l}4 \\
4 \\
4\end{array}$ & $\begin{array}{l}69 \\
39 \\
31\end{array}$ & $\begin{array}{l}2.5 \\
0.4 \\
0.2\end{array}$ & $\begin{array}{r}2.3 \\
102.0 \\
2,965.0\end{array}$ & $\begin{array}{r}0.5 \\
1.2 \\
38.0\end{array}$ \\
\hline $\begin{array}{l}\text { Depancreatized rats after } \\
\text { insulin plus salt diuresis }\end{array}$ & $\begin{array}{l}\mathrm{A}^{*} \\
\mathrm{~B} \dagger\end{array}$ & $\begin{array}{l}2 \\
2\end{array}$ & $\begin{array}{l}174 \\
177\end{array}$ & $\begin{array}{l}0.2 \\
0.2\end{array}$ & $\begin{array}{r}2.6 \\
89.0\end{array}$ & $\begin{array}{l}0.45 \\
1.7\end{array}$ \\
\hline \multicolumn{7}{|c|}{$B$} \\
\hline Normal rats & $\begin{array}{l}\mathrm{A} \\
\mathrm{C} \\
\mathrm{C} \\
\mathrm{C}\end{array}$ & $\begin{array}{l}6 \\
6 \\
6 \\
6\end{array}$ & $\begin{array}{c}\overline{-} \\
(\text { Day } 1) \\
(\text { Day 3) } \\
(\text { Day 6) }\end{array}$ & $\begin{array}{l}\overline{-} \\
\overline{-}\end{array}$ & $\begin{array}{r}1.5 \\
474.0 \\
570.0 \\
822.0\end{array}$ & $\begin{array}{r}0.2 \\
12.0 \\
2.0 \\
20.0\end{array}$ \\
\hline Alloxan diabetic & $\begin{array}{l}\mathrm{A} \\
\mathrm{C} \\
\mathrm{C} \\
\mathrm{C}\end{array}$ & $\begin{array}{l}5 \\
5 \\
5 \\
4\end{array}$ & $\begin{array}{l}(\overline{D a y} 1) \\
(\text { Day 2) } \\
\text { (Day 3) }\end{array}$ & $\begin{array}{l}18 \\
15 \\
16 \\
17\end{array}$ & $\begin{array}{r}1.6 \\
1,032.0 \\
1,091.0 \\
1,196.0\end{array}$ & $\begin{array}{r}5 \\
209 \\
228 \\
293\end{array}$ \\
\hline
\end{tabular}

* 10 per cent $\mathrm{NaCl}$ given by stomach tube. One rat received $21 \mathrm{ml}$. in seven doses, the other rat received $20 \mathrm{ml}$. in five doses.

$\dagger \mathrm{NaCl}$ added to diet -5 per cent for one rat and 10 per cent for other rat.

The intestinal absorption of inositol was measured by the method of Cori (4). Prior to study the rats were fed the low inositol diet for three days to reduce the quantity of inositol in the gut. One hundred milligrams of inositol was given by gastric tube. After six hours the inositol remaining in the intestinal tract was recovered and measured.

For studies of renal clearance, rats were anesthetized with Nembutal and a tracheotomy was performed. A polyethylene catheter was placed in either the femoral or external jugular vein and intravenous injections of

TABLE II

Intestinal absorption of inositol in normal and diabetic rats

\begin{tabular}{|c|c|c|c|c|c|}
\hline & \multirow[b]{2}{*}{$\underset{\text { ber }}{\text { Num- }}$} & \multirow[b]{2}{*}{ Weight } & \multirow[b]{2}{*}{$\begin{array}{c}\text { Hours } \\
\text { after } \\
\text { inosi- } \\
\text { tol }\end{array}$} & \multicolumn{2}{|l|}{ Inositol } \\
\hline & & & & $\underset{\substack{\text { Ing. } \\
\text { gut }}}{ }$ & $\underset{\substack{\text { In } \\
\text { urine } \\
m g .}}{\text { ma. }}$ \\
\hline $\begin{array}{l}\text { Normal rats } \\
\text { Control } \\
\text { Inositol (100 mg.) } \\
\text { Inositol (100 mg.) }\end{array}$ & $\begin{array}{l}3 \\
3 \\
6\end{array}$ & $\begin{array}{l}120 \\
137 \\
129\end{array}$ & $\begin{array}{l}\overline{0} \\
6\end{array}$ & $\begin{array}{c}1.8 \\
104 \\
73.7 \pm 2.63^{*}\end{array}$ & $\overline{\overline{1}}$ \\
\hline $\begin{array}{l}\text { Diabetic rats } \\
\text { Inositol }\end{array}$ & 6 & 104 & 6 & $54.3 \pm 5.12^{*}$ & 10.5 \\
\hline
\end{tabular}

* Standard error of mean. The difference in inositol in intestinal contents of normal and diabetic rats was significant, $\mathrm{P}=<.009$. priming and sustaining solutions were made with a simple syringe type infusion pump delivering about $8 \mathrm{ml}$. per hour. Heparin $(0.2 \mathrm{mg}$.) was added to the initial loading solution. Urine was collected by catheter (5) for 30-minute periods following which the bladder was rinsed with $0.15 \mathrm{ml}$. of normal saline solution. At the midpoint of each period blood from the tail was collected in glass tubing (OD $4 \mathrm{~mm}$.). After sealing with Pyseal the plasma was separated by centrifugation.

Inositol was measured by the method of Atkin (6) with the modifications previously described (2). The level of free inositol was determined in plasma after barium and zinc precipitation of proteins. Urine samples were not hydrolyzed routinely because it had been found in earlier experiments that inositol is excreted almost totally in the free form. Blood and urine sugar determinations were performed according to Nelson (7).

TABLE III

Levels of blood inositol before and six hours after $100 \mathrm{mg}$. of inositol by stomach tube

\begin{tabular}{|c|c|c|c|}
\hline & \multirow[b]{2}{*}{ Number } & \multicolumn{2}{|c|}{ Blood inositol } \\
\hline & & $\begin{array}{c}\text { Initial } \\
m g . / 100 \mathrm{ml} .\end{array}$ & $\begin{array}{c}6 \text { hours } \\
m g . / 100 ~ m l .\end{array}$ \\
\hline $\begin{array}{l}\text { Normal rats } \\
\text { Diabetic rats }\end{array}$ & $\begin{array}{l}5 \\
6\end{array}$ & $\begin{array}{l}\text { 2.9, S.E. } \pm .20 \\
2.3, \text { S.E. } \pm .32\end{array}$ & $\begin{array}{l}\text { 3.0, S.E.土.52 } \\
\text { 5.4, S.E.土.74 }\end{array}$ \\
\hline
\end{tabular}


A modification of the method of Folin and $\mathrm{Wu}$ (8) was used for the measurement of creatinine.

\section{RESULTS}

The infuence of dietary intake on the excretion of inositol by normal and diabetic rats

Normal rats excreted little inositol even at the highest levels of inositol intake (Table I $A$ ). Partially depancreatized diabetic rats excreted far more inositol than did the control rats at all levels of intake tested. When insulin was given to diabetic rats in doses adequate to eliminate most of the glucose from the urine, the excretion of inositol was found to be nearly normal.

Inosituria has previously been attributed to polyuria of any cause (9). For this reason an experiment was done in which osmotic diuresis was induced by salt administration in diabetic rats receiving insulin. Although urine volume increased to levels comparable to that without insulin, the excretion of inositol remained low.

TABLE IV

Renal clearance of inositol in the rat

\begin{tabular}{|c|c|c|c|c|c|c|c|c|c|c|c|c|c|c|}
\hline & \multirow[b]{2}{*}{$\begin{array}{l}\text { Period } \\
(30 \text { min. })\end{array}$} & \multicolumn{2}{|r|}{ Loading sol. } & \multicolumn{2}{|c|}{ Sustaining sol.* } & \multicolumn{3}{|c|}{ Creatinine } & \multicolumn{3}{|c|}{ Inositol } & \multirow[b]{2}{*}{ FFIRT } & \multicolumn{2}{|c|}{ Glucose } \\
\hline & & $\begin{array}{l}\text { Ino- } \\
\text { sitol } \\
m g .\end{array}$ & $\begin{array}{l}\text { Other } \\
\text { mg. }\end{array}$ & $\begin{array}{l}\text { Ino- } \\
\text { sitol } \\
\%\end{array}$ & Other & $\underset{m g . \%}{\text { Plasma }}$ & $\begin{array}{l}\text { Urine } \\
\text { mg. }\end{array}$ & $\begin{array}{l}\text { Clear- } \\
\text { ance } \\
c c . / h r .\end{array}$ & $\begin{array}{c}\text { Plasma } \\
m g . \%\end{array}$ & $\underset{\text { ing. }}{\text { Urine }}$ & $\begin{array}{l}\text { Clear- } \\
\text { ance } \\
c c . / h r .\end{array}$ & & $\begin{array}{l}\text { Blood } \\
\text { mg. \% }\end{array}$ & $\begin{array}{c}\text { Urine } \\
\text { mg. }\end{array}$ \\
\hline $\begin{array}{c}\text { Control } \\
\text { No. } 1 \\
\text { Wt. } 360 \mathrm{Gm} .\end{array}$ & $\begin{array}{l}1 \\
2 \\
3\end{array}$ & $\overline{20}$ & $\bar{E}$ & $\begin{array}{l}0 . \overline{2} \\
1\end{array}$ & & $\begin{array}{l}20 \\
13.4 \\
17.6\end{array}$ & $\begin{array}{l}25.5 \\
17.0 \\
12.3\end{array}$ & $\begin{array}{l}255 \\
254 \\
140\end{array}$ & $\begin{array}{r}1 \\
7 \\
14\end{array}$ & $\begin{array}{l}0.01 \\
0.07 \\
1.4\end{array}$ & $\begin{array}{r}2 \\
2 \\
20\end{array}$ & $\begin{array}{l}.99 \\
.99 \\
.86\end{array}$ & E & E \\
\hline $\begin{array}{c}\text { Control } \\
\text { No. } 2 \\
\text { Wt. } 453 \mathrm{Gm} .\end{array}$ & $\begin{array}{l}1 \\
2 \\
3\end{array}$ & $\begin{array}{r}\overrightarrow{20} \\
100\end{array}$ & $\overline{-}$ & $\begin{array}{l}0 . \overline{2} \\
1\end{array}$ & & $\begin{array}{l}19.5 \\
27.7 \\
31.5\end{array}$ & $\begin{array}{l}23.0 \\
26.0 \\
19.3\end{array}$ & $\begin{array}{l}234 \\
188 \\
122\end{array}$ & $\begin{array}{r}0.7 \\
17.5 \\
57.5\end{array}$ & $\begin{array}{l}0.01 \\
0.6 \\
11\end{array}$ & $\begin{array}{r}2.9 \\
6.9 \\
38.3\end{array}$ & $\begin{array}{l}.99 \\
.96 \\
.69\end{array}$ & E & E \\
\hline $\begin{array}{c}\text { Control } \\
\text { No. } 3 \\
\text { Wt. } 325 \mathrm{Gm} \text {. }\end{array}$ & $\begin{array}{l}1 \\
2 \\
3\end{array}$ & $\begin{array}{r}5 \\
10 \\
25\end{array}$ & - & $\begin{array}{l}0.01 \\
0.05 \\
0.1\end{array}$ & & $\begin{array}{l}27.3 \\
46.5 \\
57.0\end{array}$ & $\begin{array}{l}24.3 \\
32.2 \\
34.0\end{array}$ & $\begin{array}{l}178 \\
138 \\
112\end{array}$ & $\begin{array}{r}2.8 \\
7.8 \\
20.8\end{array}$ & $\begin{array}{l}<.01 \\
.03 \\
2.5\end{array}$ & $\begin{array}{l}<1 \\
24^{8}\end{array}$ & $\begin{array}{l}.99 \\
.99 \\
.79\end{array}$ & E & E \\
\hline $\begin{array}{c}\text { Diabetic } \\
\text { No. } 1 \\
\text { Wt. } 262 \mathrm{Gm} .\end{array}$ & $\begin{array}{l}1 \\
2 \\
3\end{array}$ & $\begin{array}{r}5 \\
15 \\
25\end{array}$ & - & $\begin{array}{l}0.01 \\
0.05 \\
0.1\end{array}$ & & $\begin{array}{l}23.0 \\
30.3 \\
41.2\end{array}$ & $\begin{array}{l}28.4 \\
32.9 \\
32.1\end{array}$ & $\begin{array}{l}247 \\
181 \\
156\end{array}$ & $\begin{array}{r}3.3 \\
12.7 \\
25.0\end{array}$ & $\begin{array}{l}0.5 \\
3.1 \\
8.0\end{array}$ & $\begin{array}{l}30.3 \\
48.7 \\
64.0\end{array}$ & $\begin{array}{l}.87 \\
.73 \\
.59\end{array}$ & $\frac{192}{-}$ & $\begin{array}{r}24 \\
12 \\
8\end{array}$ \\
\hline $\begin{array}{c}\text { Diabetic } \\
\text { No. } 2 \\
\text { Wt. } 364 \text { Gm. }\end{array}$ & $\begin{array}{l}1 \\
2 \\
3\end{array}$ & $\begin{array}{r}5 \\
15 \\
25\end{array}$ & E & $\begin{array}{l}0.01 \\
0.05 \\
0.1\end{array}$ & & $\begin{array}{l}18.5 \\
24.9 \\
26.8\end{array}$ & $\begin{array}{l}23.3 \\
24.8 \\
26.2\end{array}$ & $\begin{array}{l}252 \\
199 \\
196\end{array}$ & $\begin{array}{r}3.9 \\
11.4 \\
15.9\end{array}$ & $\begin{array}{l}0.5 \\
3.2 \\
8.2\end{array}$ & $\begin{array}{l}26.2 \\
56.2 \\
103\end{array}$ & $\begin{array}{l}.89 \\
.72 \\
.47\end{array}$ & $\overline{417}$ & $\begin{array}{r}188 \\
98 \\
62\end{array}$ \\
\hline $\begin{array}{l}\text { Diabetic } \\
\text { No. } 3 \\
\text { Wt. } 266 \mathrm{Gm} \text {. }\end{array}$ & $\begin{array}{l}1 \\
2 \\
3\end{array}$ & $\begin{array}{r}5 \\
15 \\
25\end{array}$ & E & $\begin{array}{l}0.01 \\
0.05 \\
0.1\end{array}$ & & $\begin{array}{r}57 \\
92 \\
116\end{array}$ & $\begin{array}{l}11.8 \\
18.8 \\
16.8\end{array}$ & $\begin{array}{l}42 \\
41 \\
29\end{array}$ & $\begin{array}{r}6.3 \\
15.9 \\
26.7\end{array}$ & $\begin{array}{l}0.8 \\
2.7 \\
4.9\end{array}$ & $\begin{array}{l}24.5 \\
33.9 \\
37\end{array}$ & $\begin{array}{c}.41 \\
.17 \\
(-.27)\end{array}$ & $\begin{array}{l}780 \\
744 \\
738\end{array}$ & $\begin{array}{r}112 \\
76 \\
46\end{array}$ \\
\hline $\begin{array}{c}\text { Glucose } \\
\text { No. } 1 \\
\text { Wt. } 288 \mathrm{Gm} \text {. }\end{array}$ & $\begin{array}{l}1 \\
2 \\
3\end{array}$ & $\begin{array}{r}5 \\
15 \\
25\end{array}$ & $600 \mathrm{mg}$. Gluc. & $\begin{array}{l}0.01 \\
0.05 \\
0.1\end{array}$ & $\begin{array}{l}15 \% \text { Gluc. } \\
15 \% \text { Gluc. } \\
15 \% \text { Gluc. }\end{array}$ & $\begin{array}{l}21 \\
37.2 \\
43.5\end{array}$ & $\begin{array}{l}17.6 \\
29.8 \\
26.2\end{array}$ & $\begin{array}{l}187 \\
160 \\
120\end{array}$ & $\begin{array}{l}3.0 \\
10.8 \\
21\end{array}$ & $\begin{array}{c}0.36 \\
3.9 \\
10.9\end{array}$ & $\begin{array}{r}24 \\
72 \\
104\end{array}$ & $\begin{array}{l}.84 \\
.55 \\
.14\end{array}$ & $\begin{array}{l}516 \\
554 \\
584\end{array}$ & $\begin{array}{l}238 \\
306 \\
334\end{array}$ \\
\hline $\begin{array}{c}\text { Glucose } \\
\text { No. } 2 \\
\text { Wt. } 273 \mathrm{Gm} .\end{array}$ & $\begin{array}{l}1 \\
2 \\
3\end{array}$ & $\begin{array}{r}5 \\
15 \\
25\end{array}$ & $900 \mathrm{mg}$. Gluc. & $\begin{array}{l}0.01 \\
0.05 \\
0.1\end{array}$ & $\begin{array}{l}15 \% \text { Gluc. } \\
15 \% \text { Gluc. } \\
15 \% \text { Gluc. }\end{array}$ & $\begin{array}{l}16.8 \\
46.5 \\
52.2\end{array}$ & $\begin{array}{l}15.4 \\
29.2 \\
28.2\end{array}$ & $\begin{array}{l}183 \\
126 \\
108\end{array}$ & $\begin{array}{r}3.6 \\
9.6 \\
17.2\end{array}$ & $\begin{array}{l}0.47 \\
2.4 \\
7.7\end{array}$ & $\begin{array}{l}26 \\
50 \\
90\end{array}$ & $\begin{array}{l}.86 \\
.66 \\
.17\end{array}$ & $\begin{array}{l}655 \\
850 \\
910\end{array}$ & $\begin{array}{l}380 \\
284 \\
364\end{array}$ \\
\hline $\begin{array}{c}\text { Glucose } \\
\text { No. } 3 \\
\text { Wt. } 303 \mathrm{Gm} \text {. }\end{array}$ & $\begin{array}{l}1 \\
2 \\
3\end{array}$ & $\begin{array}{r}5 \\
20 \\
40\end{array}$ & $600 \mathrm{mg}$. Gluc. & $\begin{array}{l}0.01 \\
0.05 \\
0.1\end{array}$ & $\begin{array}{l}10 \% \text { Gluc. } \\
10 \% \text { Gluc. } \\
10 \% \text { Gluc. }\end{array}$ & $\begin{array}{l}18.0 \\
37.8 \\
43.5\end{array}$ & $\begin{array}{l}15.4 \\
31.0 \\
34.6\end{array}$ & $\begin{array}{l}171 \\
164 \\
159\end{array}$ & $\begin{array}{r}4.2 \\
13.8 \\
27.8\end{array}$ & $\begin{array}{c}0.35 \\
3.3 \\
15.2\end{array}$ & $\begin{array}{l}16.8 \\
48.4 \\
109\end{array}$ & $\begin{array}{l}.90 \\
.70 \\
.32\end{array}$ & $\begin{array}{l}442 \\
468 \\
526\end{array}$ & $\begin{array}{l}205 \\
185 \\
208\end{array}$ \\
\hline $\begin{array}{c}\text { Phlorizin } \\
\text { No. } 1 \\
\text { Wt. } 400 \mathrm{Gm} .\end{array}$ & $\begin{array}{l}1 \\
2 \\
3\end{array}$ & $\frac{15}{-}$ & 187 mg. Phlor. & $\begin{array}{l}0.1 \\
0.1 \\
0.1\end{array}$ & & $\begin{array}{l}17.3 \\
43.6 \\
49.7\end{array}$ & $\begin{array}{l}19.8 \\
26.1 \\
30.3\end{array}$ & $\begin{array}{l}229 \\
120 \\
122\end{array}$ & $\begin{array}{l}14.1 \\
15.0 \\
14.7\end{array}$ & $\begin{array}{l}4.3 \\
5.8 \\
4.4\end{array}$ & $\begin{array}{l}61 \\
77 \\
60\end{array}$ & $\begin{array}{l}.73 \\
.36 \\
.55\end{array}$ & $\begin{array}{l}114 \\
131 \\
127\end{array}$ & $\begin{array}{l}\overline{64} \\
49\end{array}$ \\
\hline $\begin{array}{c}\text { Phlorizin } \\
\text { No. } 2 \\
\text { Wt. } 296 \mathrm{Gm} \text {. }\end{array}$ & $\begin{array}{r}1 \\
2 \\
3\end{array}$ & $\frac{15}{-}$ & $187 \mathrm{mg}$. Phlor. & $\begin{array}{l}0.1 \\
0.1 \\
0.1\end{array}$ & & $\begin{array}{l}26.2 \\
48.9 \\
67.2\end{array}$ & $\begin{array}{l}22.9 \\
26.7 \\
36.2\end{array}$ & $\begin{array}{l}175 \\
109 \\
108\end{array}$ & $\begin{array}{l}23.8 \\
23.8 \\
20.0\end{array}$ & $\begin{array}{l}1.9 \\
4.6 \\
4.1\end{array}$ & $\begin{array}{l}16 \\
39 \\
41\end{array}$ & $\begin{array}{l}.91 \\
.65 \\
.62\end{array}$ & $\begin{array}{l}144 \\
148 \\
184\end{array}$ & $\begin{array}{l}\overline{60} \\
57\end{array}$ \\
\hline
\end{tabular}

* Mannitol (3 per cent) was added to all hypotonic sustaining solutions. Mannitol was found not to affect inositol reabsorption. Creatinine (1 per cent) was present in all sustaining solutions.

$\dagger$ Fraction of filtered inositol reabsorbed $\left(1-\frac{\text { Clearance of inositol }}{\text { Clearance of creatinine }}\right)$. 


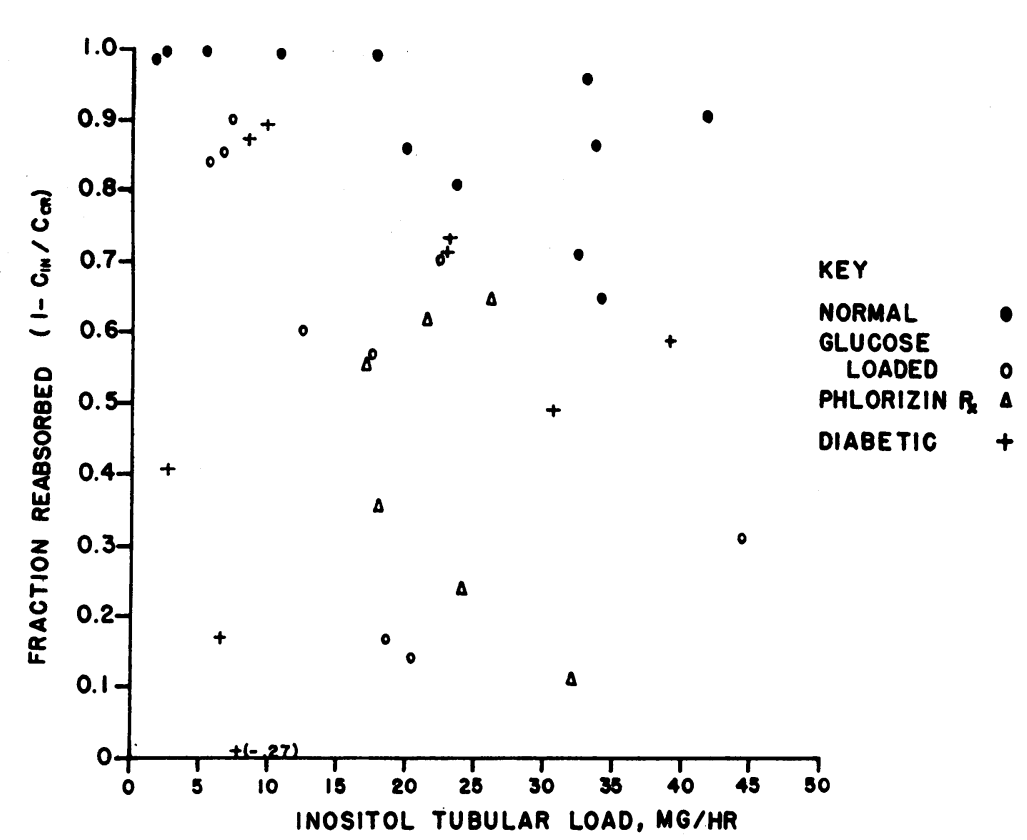

Fig. 1. A Plot of Tubular load (Plasma Inositol Level X Creatinine Clearance) against Fraction of the Tubular Load Reabsorbed

The results presented in Table I $B$ indicate that the inosituria of alloxan diabetic rats is comparable to that occurring in partially depancreatized rats. Whereas normal rats excrete negligible amounts of large oral doses of inositol, alloxan diabetic rats excreted 20 to 25 per cent of that ingested.

\section{Intestinal absorption of inositol}

Little inositol was present in the gut prior to inositol administration and recovery was virtually complete immediately after inositol administration (Table II). Normal rats were found to have absorbed 26 per cent and the diabetic rats 46 per cent of the inositol which had been given six hours previously. This difference was found to be significant $(p=<.009)$.

Because of the somewhat faster absorption of inositol from the gut by diabetic rats the concentration of inositol in the blood after acid hydrolysis has been determined before and six hours after the intragastric administration of $100 \mathrm{mg}$. of inositol. The mean level of blood inositol in fasted normal rats was slightly higher than that of diabetic rats but the difference is not significant (Table III). The blood inositol level after six hours in the diabetic rats was significantly higher than in the control group $(p=<.04)$, despite the higher urinary excretion in the diabetic rats.

\section{The renal clearance of inositol}

At low levels of plasma inositol the renal clearance of inositol is very small in normal rats (Table IV). If the assumption is made that all the free plasma inositol is available for filtration the tubular load of inositol can be calculated. In Figure 1 the tubular load has been plotted against the fraction of filtered inositol reabsorbed $\left(1-\mathrm{C}_{\mathrm{In}} / \mathrm{C}_{\mathrm{cr}}\right)$ which is indicated on the table as "FFIR." It is apparent that inositol reabsorption is virtually complete with tubular loads up to $17 \mathrm{mg}$. per hour. Thereafter increasing amounts of inositol appear in the urine. At tubular loads higher than presented in Figure 1, the inositol reabsorption increased despite inosituria and it has not been possible to define a definite $T \mathrm{~m}$ for inositol.

The inositol clearance of diabetic rats was at least ten times that of the non-diabetic rat. Glomerular filtration was impaired in the most severely diabetic rat (Diabetic No. 3). Whether this was due to alloxan injury or was a result of the severe diabetes could not be determined. The observation of a higher inositol clearance than creatinine clearance in Period 3 may represent an analytic error.

Glucose loading experiments were performed to distinguish the effects of hyperglycemia and 
glycosuria per se from the other metabolic effects of insulin insufficiency. Consistent elevations of blood sugar were not obtained by intraperitoneal or subcutaneous administration of glucose. $\mathrm{Hy}$ perglycemia and glycosuria were induced by the intravenous infusion of glucose in three rats and the inositol and creatinine clearances were measured (Table IV). An increase in inositol clearance was observed under these conditions up to the range of that found in diabetes.

Phlorizin in a dose of $187 \mathrm{mg}$. intravenously was given to observe the effect on inositol clearance. Clearance measurements on two rats are presented in Table IV. In both rats there was a substantial reduction of the fraction of the inositol which was reabsorbed by the renal tubule.

\section{DISCUSSION}

The presence of increased amounts of inositol in the urine of rats with experimental diabetes is clearly established. Quantitatively the inosituria of diabetic rats is determined by inositol intake. The contention of Needham that "inosituria is associated with polyuria of whatever origin" (9) is not supported by the failure of a salt induced diuresis to re-establish the inosituria of diabetic rats receiving insulin.

In searching for other explanations for the increased excretion of inositol in diabetes mellitus the rate of gastrointestinal absorption and the mechanism of the renal excretion of inositol have been investigated. The intestinal absorption of inositol by normal rats is slower than that of the common hexoses and pentoses. Under the conditions examined an average of $3.4 \mathrm{mg}$. of inositol per 100 grams of rat was absorbed per hour as compared to the reported rate of $172 \mathrm{mg}$. of glucose per 100 grams of rat per hour (6). These findings agree with the more complete observations of Wiebelhaus, Betheil, and Lardy (10). The faster absorption of inositol from the gut of diabetic rats results in higher blood levels of inositol but probably contributes relatively little to the inosituria of such animals.

The studies of inositol clearance in the rat confirm the previous observation in man that inositol is virtually completely reabsorbed from the glomerular filtrate and the reabsorption of inositol is inhibited by glucosuria. A quantitative differ- ence exists between the rat and the human being in respect to the degree of inhibition of inositol reabsorption by glucosuria. Inositol reabsorption was nearly totally abolished by glucose in the human; whereas, the inhibition in the rat proved incomplete and required a high glucose load for its demonstration. The relative specificity of the inhibition by glucose is suggested by the lack of effect of an osmotic diuresis produced by sodium chloricle on inositol excretion. The addition of mannitol to hypotonic infusion solutions was also without effect on inositol excretion although diuresis occurred. The above data suggest that glucose and inositol may compete for the same tubular reabsorptive mechanism. The reabsorption of xylose has also been attributed to the glucose transport mechanism on the basis of similar evidence, namely the inhibition of xylose reabsorption by glucose and phlorizin (11). The interpretation of the action of phlorizin on inositol and xylose reabsorption is difficult. It is not possible to state to what extent the reabsorptive mechanism is inhibited by phlorizin directly and to what extent the inhibition is secondary to glycosuria.

\section{SU MIMARY}

1. Depancreatinized and alloxan diabetic rats excrete much more inositol in their urine than do normal rats.

2. Whereas the inositol in the urine of normal rats is little influenced by dietary intake. that of diabetic rats is correlated directly with the amount of inositol ingested.

3. Diabetic rats absorbed inositol faster from the gut than did normal rats. The average inositol level in the blood of diabetic rats after oral inositol was found to be slightly higher than that of normal rats despite an increase in urinary excretion of inositol.

4. An active tubular reabsorption of inositol exists. The reabsorption of inositol is inhibited in diabetic rats, in rats with non-diabetic glycosuria and in phlorizin treated rats. An osmotic diuresis produced by sodium chloride did not result in inosituria comparable to that found in diabetes.

5. It is concluded that the inosituria of diabetes mellitus can be attributed to an increase in the renal clearance of inositol produced by glycosuria. 


\section{ACKNOWLEDGMENT}

This study was initiated (by J. L.) in the laboratory of Dr. Herbert E. Carter of the University of Illinois. The authors wish to thank Dr. Carter for his assistance and continued interest in these investigations. The operations of subtotal pancreatectomy were performed by $\mathrm{Dr}$. D. J. Ingle at the laboratories of the Upjohn Company of Kalamazoo, Michigan.

\section{REFERENCES}

1. Neukomm, J., Ueber das vorkommen von Leucin, Tyrosin und anderer Umsatzstoffe in Menschlichen Körper bei Krankheiten. Zürich, Orell, Füssli u. Comp., 1859, 48 p. (Dissertation) (quoted by Needham, J. [9] ).

2. Daughaday, W. H., and Larner, J., The renal excretion of inositol in normal and diabetic human beings. J. Clin. Invest., 1954, 33, 326.

3. Jones, J. H., and Foster, C., A salt mixture for use with basal diets either low or high in phosphorus. J. Nutrition, 1942, 24, 245.
4. Cori, C. F., The fate of sugar in the arimal body. I. The rate of absorption of hexoses and pentoses from the intestinal tract. J. Biol. Chem., 1925, 66, 691.

5. Ames, R. G., and van Dyke, H. B., Antidiuretic hormone in the serum or plasma of rats. Endocrinology, 1952, 50, 350.

6. Gyory, P., ed., Vitamin Methods, I, New York, Academic Press, 1950.

7. Nelson, N., A photometric adaptation of the Somogyi method for the determination of glucose. J. Biol. Chem., 1944, 153, 375.

8. Folin, O., and Wu, H., A system of blood analysis. J. Biol. Chem., 1919, 38, 81.

9. Needham, J., Studies on inositol. II. The synthesis of inositol in the animal body. Biochem. J., 1924. 18, 891 .

10. Wiebelhaus, V. D., Betheil, J. J., and Lardy, H. A., The metabolism of meso-inositol in the rat. Arch. Biochem., 1947, 13, 379.

11. Smith, H. W., The Kidney, Structure and Function in Health and Disease. New York, Oxford Uni versity Press, 1951. 